\title{
A Case of Prenatal Diagnosis of Trisomy 18 with Ultrasound
}

\section{Kasus Diagnosis Prenatal pada Trisomi 18 dengan Ultrasonografi}

\author{
Yusrawati, Yudha M Kartika \\ Division of Fetomaternal Medicine \\ Department of Obstetrics and Gynecology \\ Faculty of Medicine Andalas University/ \\ Dr. M. Djamil General Hospital \\ Padang
}

\begin{abstract}
Objective: To report a case of trisomy 18 diagnosed in prenatal care. Methods: Case report.

Case: A 24 years old primigravida woman was diagnosed with term pregnancy (37-38 weeks) with an intrauterine singleton live fetus with Edwards syndrome. In 15-16 weeks of pregnancy the omphalocele was discovered using ultrasound. Subsequently, amniocentesis was performed and the chromosome analysis result showed Edwards syndrome $(47, \mathrm{XX}+18)$. The patient chose to continue the pregnancy until term. In this patient, elective CS was performed at term pregnancy, involving teamwork between obstetrics and perinatology. A female baby was born weighing 1720 grams, $40 \mathrm{~cm}$ body length, and APGAR score of 5/7. The congenital anomalies discovered include umbilical hernia, rocker bottom feet, clenched hands, low set malformed ears, and a single umbilical artery. The baby was born with asphyxia, improved after resuscitation, and required treatment in the NICU. Pediatric surgeons planned umbilical hernia repair. Furthermore, because of the presence of suspected esophageal atresia, the baby was planned for gastrotomy, which was delayed because the baby was experiencing desaturation. Because of the unstable condition of the baby, echocardiography and gastrotomy were not done until the $18^{\text {th }}$ day of treatment. At the $18^{\text {th }}$ day, the baby's condition deteriorated and the baby died with metabolic acidosis.
\end{abstract}

Conclusion: Edwards syndrome can be diagnosed in the prenatal period by risk factors consideration, maternal serum markers, and ultrasonographic identification of organ abnormalities.

[Indones J Obstet Gynecol 2015; 3-4: 234-238]

Keywords: Edwards syndrome, prenatal diagnosis, trisomy 18, ultrasound

\begin{abstract}
Abstrak
Tujuan: Melaporkan kasus trisomi 18 yang didiagnosa pada masa prenatal.

Metode: Laporan kasus.

Kasus: Seorang perempuan $G_{1} P a A O H o, 24$ tahun, didiagnosa dengan kehamilan aterm (37-38 mingou), janin tunggal hidup intrauterin dengan sindroma Edward. Pada usia kehamilan 15-16 minggu dijumpai omfalokel pada ultrasonografi sehingga dilakukan amniosintesis, dan dari hasil analisa kromosomnya didapatkan sindroma Edwards (47, XX +18). Pasien memilih untuk melanjutkan kehamilan hingga cukup bulan. Pada pasien ini dilakukan SC elektif pada kehamilan aterm dengan kerjasama tim kebidanan dan perinatologi. Lahir bayi perempuan dengan berat badan 1720 gram, panjang badan $40 \mathrm{~cm}$, dan APGAR skor 5/7. Dijumpai kelainan kongenital berupa hernia umbilikalis, rocker bottom feet, clenched hands, telinga malformasi letak rendah, dan arteri umbilikalis tunggal. Bayi lahir dengan asfiksia, membaik setelah resusitasi, dan memerlukan perawatan NICU. Ahli bedah anak merencanakan reparasi hernia umbilikalis. Karena diduga adanya atresia esophagus, direncanakan gastrotomi, namun gastrotomi ditunda karena bayi mengalami desaturasi. Dikarenakan kondisi bayi tidak stabil maka echocardiography dan gastrotomi belum dilakukan hingga hari ke-18 perawatan. Pada hari ke-18 perawatan, bayi mengalami perburukan dan meninggal dengan asidosis metabolik.
\end{abstract}

Kesimpulan: Sindroma Edwards dapat didiagnosa pada masa prenatal dengan memperhatikan faktor risiko, marker serum pada maternal, dan temuan kelainan organ melalui ultrasonografi.

[Maj Obstet Ginekol Indones 2015; 3-4: 234-238]

Kata kunci: diagnosa prenatal, sindroma Edwards, trisomi 18, ultrasonografi

\section{INTRODUCTION}

Trisomy 18, also known as Edwards syndrome, is an autosomal chromosomal disorder due to an extra chromosome 18. The first fetal reports were described by Edwards et al and Smith et al in 1960 . The prevalence in female infants is higher than in male infants (female-to-male percentage ratio 60:40), but this tendency is not identified if the sex ratio was calculated in infants born electively (fe- male-to-male percentage ratio 48:51). The frequency of fetal death is higher in male than female fetuses. The female infants born alive showed a better survival than male infants. ${ }^{1}$ Its overall incidence is 1 in 6,000 live births. The risk increases with increasing maternal age. In the UK, as many as 495 cases of trisomy 18 were diagnosed in 2008-2009, 92\% of them were diagnosed prenatally, and only 35 cases (10.32\%) were born alive. $^{2}$ 
Edwards syndrome is genetically characterized by the presence of an extra chromosome 18, in whole or partially (by the process of translocation or mozaic-type). Ovum or sperm cells contain 23 chromosomes that will eventually form the 46 chromosomes. In the second meiotic division, if there is non-disjunction the resulting extra chromosome will lead to a total chromosome of 24 . Fertilization of the ovum or insemination by sperm containing the extra chromosome would produce trisomy, or three copies of a chromosome. Trisomy $18(47 \mathrm{XY},+18)$ is due to meiotic non-disjunction events. With non-disjunction, a gamete (sperm or ova) are produced with an extra chromosome 18, gametes then has 24 chromosomes. When joined with a normal gamete, the embryo has 47 chromosomes with an extra chromosome 18 . On rare occasions, a portion of chromosome 18 is attached to another chromosome (translocated) before or after conception. Abnormalities in infants with partial trisomy of chromosome 18 is less severe when compared with Edwards syndrome. ${ }^{2,3}$

Babies with Edwards syndrome tend to have a low birthweight, microcephaly, small chin (micrognathia), malformations of the ear, heart and kidney malformations, omphalocele, esophageal atresia, mental retardation, clenched fists and foot malformations (clubfoot or rocker bottom feet), arthrogryposis, and undescended testes for male babies. In the mozaic type of Edwards syndrome or partial trisomy 18, most of the body's cells have trisomy 18 , while the other part does not, in which case the clinical symptoms can vary from mild to complex. ${ }^{2}$

Edwards syndrome diagnosis may be suspected at the time of ultrasonographic examination, when the fetus' body structure looks abnormal. Early detection can help patients decide the continuation of pregnancy and childbirth preparation. Fetal clinical condition indicating the presence of Edwards syndrome include nuchal translucency that is more than the average, choroid plexus cysts, polyhydramnios, IUGR, microcephaly, non-immune hydrops fetalis, exomphalos (omphalocele or gastroschisis), palatoschisis, and clenched hand. By looking at the structure of fetal abnormalities with ultrasound, then amniocentesis examination can be done at 16-18 weeks of gestation for chromosome analysis. In omphalocele diagnosed by ultrasound in the first trimester or in the second trimester examination is needed to determine the genetic configuration. ${ }^{4}$
There is no genetic therapy for Edwards syndrome. Babies with Edwards syndrome frequently have major physical abnormalities which can be corrected with surgery based on the level of severity, but extreme invasive procedures are not performed on infants whose predicted survival is quantified in a matter of days or weeks. Medical therapy can be performed with the goal of palliation but not life extension. Edwards syndrome is a serious condition and can cause severe medical problems. Often these cases of trisomy 18 die before birth or during labor. In infants born alive, the average lifespan is $5-15$ days, $50 \%$ survive to 1 month of age, and only $<10 \%$ can survive more than 1 year. $^{2}$

\section{CASE}

A 24 years old primigravida patient was treated in the obstetrics ward of Ibnu Sina Islamic Hospital, Padang on April $4^{\text {th }}, 2014$ with term pregnancy (37-38 weeks) of an intrauterine singleton living fetus with head presentation with omphalocele. The patient was not in labor and in good general condition.

Patient had antenatal care at the maternity clinic of Ibnu Sina Islamic Hospital, Padang. On the 4.5 months visit, there was the possibility of abnormalities in the fetal stomach, patients are encouraged to check the amniotic fluid and then the results of chromosome analysis of amniotic fluid identified Edwards syndrome (trisomy 18) without major structural abnormalities.

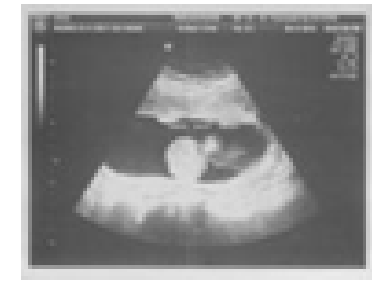

(a)

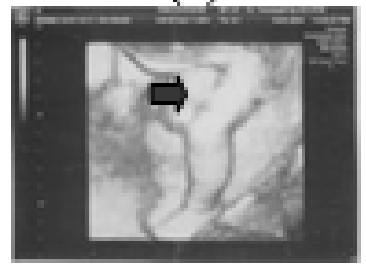

(b)

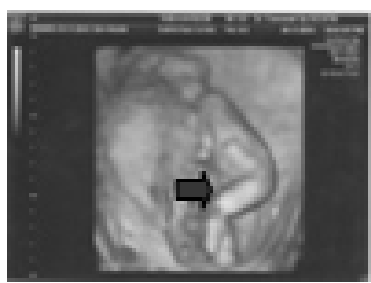

(b)

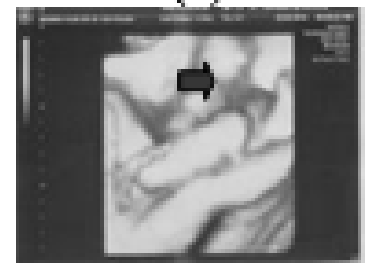

(d)
Figure 1. Ultrasound at 18-19 weeks (a and b), 26-27 weeks (c), and 31-32 weeks (d), showing the presence of omphalocele (red arrows) 
At 37-38 weeks of pregnancy, ultrasound biometry obtained BPD: $9.25 \mathrm{~cm}$, HL: $5.83 \mathrm{~cm}$, FL: 6.68 $\mathrm{cm}, \mathrm{AC}: 27.62 \mathrm{~cm}$, with an estimated weight of 2269 grams and the fetal abdominal organs was found outside the abdominal cavity, which was diagnosed as omphalocele.

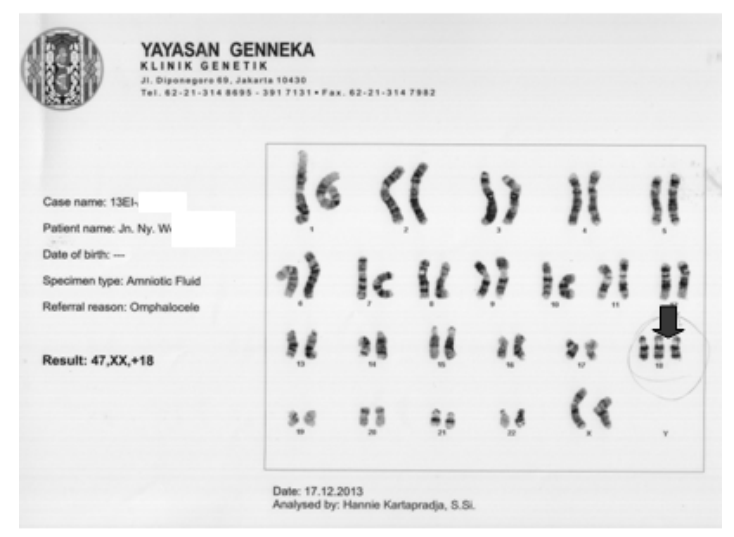

Figure 2. Result of chromosome analysis

Chromosome analysis was performed on samples derived from amniotic fluid obtained by amniocentesis. With G-Banding techniques, chromosomes of 20 cells from three different cell culture preparations were studied, and the number of chromosomes in each cell studied was found to be $47, \mathrm{XX},+18$. This meant that the number of chromosomes was 47 with fetal sex chromosomes being XX, and an excess of 1 piece of chromosome 18 (trisomy 18). This disorder was called Edwards Syndrome. Major structural abnormalities were not identified. Abnormality of trisomy 18 usually occurs spontaneously/denovo due to non-disjunction in the process of cell division in meiosis 1 or 2. The number of repetition was very small and was unlikely to be derived from the patient's parents. Therefore, examination of the parents' chromosome in was not required. The impression from the examinations performed was Edwards syndrome without major structural abnormalities.

In this patient, an elective CS was planned. At the time of delivery, which was attended by a perinatologist, a female baby was born weighing 1720 gram, body length measuring at $40 \mathrm{~cm}$, Apgar score $5 / 7$. The placenta was born with light traction on the cord, and was found to be complete. The size of the placenta was $16 \times 17 \times 2.5 \mathrm{~cm}, 350$ grams in weight, $30 \mathrm{~cm}$ in cord length, paracentral insertion. Congenital abnormalities encountered include herniated umbilical cord, rocker bottom feet, clenched hand, low set malformed ear, and one umbilical artery. The baby was born with asphyxia, which improved after 5 minutes of resuscitation. Clinically, no heart-lung abnormality was found, and the baby required care in the NICU. Perinatologist recommended an echocardiography to ensure that cardiac abnormalities that are usually found in Edwards syndrome were not present. The baby received ampicillin sulbactam and gentamicin. The pediatric surgeons planned to repair the umbilical hernia. Furthermore, because of the presence of suspected esophageal atresia, the baby was planned for gastrotomy, but the gastrotomy was delayed because the baby suffered desaturation. Due to the unstable condition of the baby, the echocardiography and gastrotomy cannot be done until the 18th day of treatment. On the $18^{\text {th }}$ day of treatment the baby experienced a deterioration, desaturation, and metabolic acidosis; and at $12 \mathrm{pm}$ the baby was pronounced dead.

\section{DISCUSSION}

In this case, a 24 years old primigravid patient was diagnosed with term pergnancy (37-38 weeks) and omphalocele and Edwards syndrome, who was treated in the obstetrics ward and planned for elective cesarean section managed by obstetricians and perinatologist. Although the patient had known the possibility of congenital abnormalities in the fetus, the patient decided to continue the pregnancy and wanted comprehensive management of labor and for her baby. Prior to elective cesarean section, this case was consulted to perinatology for management of the possible congenital anomalies encountered at birth.

The baby was born with asphyxia, but improved after resuscitation, the perinatologist decides treatment of the infant in the NICU. Congenital abnormalities encountered in the infant include a herniated umbilical cord, rocker bottom feet, clenched hand, low set malformed ear, and singular umbilical artery. Birth weight of the baby indicates the presence of IUGR, with the baby weighing 1720 grams. There were suspected abnormalities in the baby's heart and lungs, thus the perinatologist recommended echocardiography examination. The pediatric surgeon planned to repair the umbilical hernia. Furthermore there was suspected esophageal atresia, and thus a gastrotomy was planned. The infant had been with stable condition, but worsened on the $18^{\text {th }}$ day of treatment, and finally died after 18 days of intensive care. 
This patient was diagnosed with fetal omphalocele in pregnancy through an ultrasound examination. Ultrasound plays an important role in the determination of prenatal diagnosis, providing better and more accurate prenatal diagnosis. ${ }^{5}$ This patient was diagnosed in the second trimester of pregnancy. The obstetrician who handled the pregnancy diagnosed the presence of omphalocele. The diagnosis was based on the presence of abdominal organs outside the abdominal cavity visualized on ultrasound examination. The diagnosis of omphalocele can be confirmed when the lateral ectomesodermal folds fails to meet at the midline, leaving the stomach contents only covered by the two plated amniotic sac and peritoneum. Prenatal diagnosis of omphalocele should be immediately followed by karyotyping from the amniotic fluid, and ultrasonographic scanning of the fetal heart and intestines. In this patient, after the diagnosis of omphalocele, amniocentesis was performed with the result of Edwards syndrome without major structural abnormalities (trisomy 18). This is in accordance to previous literature, stating that fetal omphalocele can be associated with a genetic disorder of trisomy $18 .^{5-7}$

Babies with omphalocele need to be delivered in a hospital with perinatologists and pediatric surgeons. Infants with omphalocele require care in the neonatal intensive care unit after they are born. Labor in fetus with omphalocele is controversial, considering the possibility of vaginal delivery with birth-related vaginal trauma and rupture of the fetal omphalocele. Therefore, abdominal delivery is the right choice. Avoiding vaginal delivery and choosing cesarean section before the onset of labor improves neonatal outcomes. Complications of vaginal delivery include ruptured omphalocele pockets, compression of intestines caused by uterine contractions, and visceral exposure to the existing bacterial flora in the lower genital tract. 8,9 However Eyal et al concluded in adequate data exists to support cesarean section as being more beneficial for the fetus compared to vaginal delivery, and there was no difference in morbidity, mortality, and incidence of visceral injury in neonates. ${ }^{10}$

There are three approaches to treat the omphalocele; a primary repair, repair at a later time, and non-surgical approach. A primary repair surgery usually occurs within 1-2 days after the baby is born. This is done if the baby has a small omphalocele, and the stomach contents can be easily placed back in the baby's abdomen, with the omphalocele contained in a special bag. During 5-7 days the surgeon will push little by little, until the viscera can be returned to the baby's stomach, until it can be closed with surgery. Prior to infants recovering from intestinal surgery, the baby will not be able to eat, and should be treated intravenously. Babies can still be fed, just not directly. ${ }^{11}$

Non-operative approach is usually the only option available for a large omphalocele. This is because there are several abdominal organs outside the body (usually the liver, stomach, and intestines) and these babies often do not have the stomach big enough to hold it all back. In this case, omphalocele babies will be covered with a special cream to help the growth of new skin on top of the membrane. Finally, when the baby is older, surgery is performed to put the organs back into the abdominal cavity. ${ }^{12}$ If normal chromosomes and no birth defects is present in addition to omphalocele, the severity of disability depends entirely on the size of the omphalocele. ${ }^{12,13}$

Babies with Edwards syndrome have a low life expectancy, with an average lifespan of 5-15 days, with the cause of death being heavy malformations of the heart or other organs. At 18 days of intensive care, the baby in our case experienced dyspnea, and later became apneic, and after resuscitation finally died. This condition was due to desaturation and metabolic acidosis in the infant.

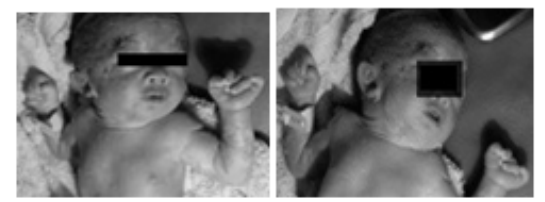

(a)

(b)

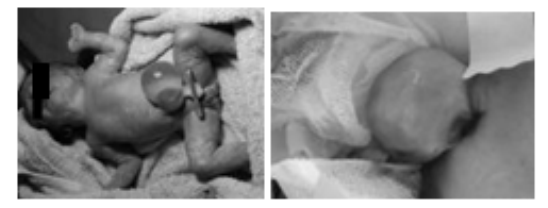

(c)

(d)

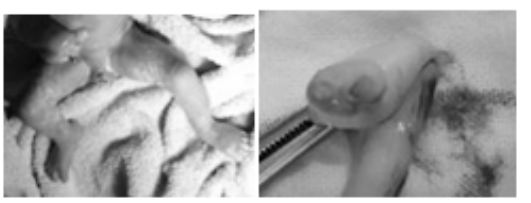

(e)

(f)

Figure 3. Baby $W$ with Edwards syndrome, (a) clenched hand, (b) low set malformed ear, (c and d) umbilical cord hernia, (e) rocker bottom feet, and (f) single umbilical artery. 


\section{CONCLUSION}

Edwards syndrome can be diagnosed in the prenatal period by taking into account risk factors including maternal age, screening of maternal serum markers, and detection of organ abnormalities by ultrasound. There is no cure for Edwards syndrome. Palliative procedures are performed for those who choose to continue the pregnancy. Most infants with Edward syndrome die intrauterine. After delivery, 20-30\% will die within one month, and $10 \%$ of babies born alive will last up to one year.

\section{REFERENCES}

1. Cereda A and Carey JC. The trisomy 18 syndrome. Orphanet J Rare Disease 2012; 7: 81.

2. National Health Service. Edwards' Syndrome (trisomy 18 or T18) information for health professionals. NHS Fetal Anomaly Programme. UK National Screening Committe, University of Exeter, 2009.

3. Sadler TW. Gametogenesis: Conversion of Germ Cell into Male and Female Gametes. In: Langman's Medical Embryology. 8th ed. Montana: Twin Bridges; 2005.

4. Agnieszka S, Slezak R, Pesz K, et al. Prenatal diagnosis-principles of diagnostic procedures and genetic counseling. Folia Histochemica et Cytobiologica 2007; 45 (Suppl1): 11-6.
5. Cunningham FG. Genetics and Prenatal Diagnosis and Fetal therapy. In: Williams Obstetric. $23^{\text {rd }}$ ed. New York: The McGraw Hill Companies; 2010.

6. Blazer S, Zimmer EZ, Gover A, et al. Fetal omphalocele detected early in pregnancy: Associated anomalies and outcomes. Radiol. 2004; 232(1): 191-5

7. Mac BT, Robbins JM, Druschel C, et al. Demographic and environmental risk factors for gastroschisis and omphalocele in the national birth defects prevention study. J Pediat Sur 2009; 44(8): 1546-51.

8. Roland A, Quijano F, Boos R, et al. Omphalocele and Gastroschisis: prenatal diagnosis and peripartal management. A case analysis of the years 1989-1997 at the Department of Obstetrics and Gynecology, University of Homburg/Saar. Eur J Obstet Gynecol Reprod Biol 1999; 87(1): 47-54.

9. Lurie S, Sherman D, Bukovsky I. Omphalocele delivery enigma: the best mode of delivery still remains dubious. Eur J Obstet Gynecol Reprod Biol 1999; 82(1): 19-22.

10. Anteby EY, Yagel S. Route of Delivery of fetuses with structural anomalies. Eur J Obstet Gynecol Reprod Biol 2003; 106(1): 5-9.

11. Collins SR, Griffin MR, Arbogast PG. The rising prevalence of gastroschisis and omphalocele in Tennessee. J Pediat Sur, 2007; 42(7): 1221-4.

12. Kumar HR, Jester AL, Ladd AP. Impact of omphalocele size and associated conditions. J Pediat Sur 2008; 43(12): 2216-9.

13. Whitehouse JS, David MG, Abbey RM, et al. Conservative management of giant omphalocele with topical povidoneiodine and its effect on thyroid function. J Pediat Sur 2010; 45(6): 1192-7. 